\title{
1. Introduction: security and the environment - the link
}

\author{
Ashok Swain, Joakim Öjendal and Anders Jägerskog
}

\section{INTRODUCTION}

Since the end of the Cold War, there is much evidence that environmental stress is becoming a main catalyst for creating societal insecurity, which may or may not result in armed conflict and the loss of lives (GPI 2019). Probably even more significant are the climatic changes and the ensuing elusive scarcity that structurally affects livelihood, poverty and food security. Moreover, there are now several indirect and dynamic effects of environmental problems and resource scarcity of renewable natural resources. It is increasingly being argued that climate change will intensify environmental stress and might even create new conflict patterns (GPI 2019). These would include resource scarcity-induced population migration, which has become a source of turbulence, social misery and violent conflicts, as well as the loss of living space and sources of livelihood attributable to climate change. Most likely, the mass movement of populations, land degradation, shifting rainfall patterns, livelihood crises, global health challenges, and food deficiency due to climate change will create security concerns for nation states, for communities and for individuals alike. The recent COVID-19 crisis has accentuated the challenges that pandemics play for security - both in traditional terms but also, and importantly, human security terms. Hence, we are facing sources of insecurity far from the traditional conceptions as typically seen in the realist paradigm (Carr 1939; Morgenthau 1948; Waltz 1979).

Environmental scarcity in the context of climate change has already changed the discourse of international politics, bringing the hegemonic conservative military security paradigm into question (Barnett 2001). Although the geopolitical dimensions and military security consequences of climate change-induced environmental scarcity pose a severe challenge to interstate relations, the adverse impact on the security of communities and individuals is, arguably, the most worrying.

The world is becoming warmer much faster than it has ever in the last 2000 years (University of Bern 2019). If the present trend of greenhouse gas emissions continues, the UN Climate Science Panel warns of the possibility of a sea-level rise of between 61 centimetres and 1.1 metres by 2100 (IPCC 2019a). The rise of the seawater level to this magnitude will inundate the highly populous low-lying countries and coastal zones of China, India, Egypt, Brazil, Mozambique, Bangladesh, and many small island states in the Pacific and Indian Ocean. Way back in 1987, the then president of Indian Ocean island country the Maldives, Maumoon Abdool Gayoom, made an emotional appeal in the UN General Assembly that a sea-level rise of only one metre would threaten the life and survival of all his countrymen (Gayoom 1987). More than three decades have passed, and the threat of several small island countries disappearing from the global map altogether looks more real than ever before. 
With sea-level rise, the world is also expected to witness serious storm surges at regular intervals as tropical cyclones will combine with higher sea levels (Vaughan 2019). This is likely to enhance the risk of coastal high flooding, particularly in the tropics. Climate change also threatens to change the regular rainfall pattern, which can potentially lead to further intensive flooding, drought and soil erosion in tropical and arid regions of the world. Food production has already been affected due to extreme weather, unpredictable seasonal changes and wildfires. The Fourth National Climate Assessment Report of the US Global Change Research Program (USGCRP 2018) warns that heatwaves, drought, wildfires and storms will increasingly disrupt agricultural productivity bringing serious food insecurity and loss of farming jobs. The UN Climate Science Panel recommends various adaption and mitigation strategies to address climate change-induced food insecurity by improving sustainable food production and more plant-based food consumption, reducing deforestation and increased afforestation programs, agricultural carbon sequestration and reduction in food waste (IPCC 2019b).

Hence, the concept of human security has come to the forefront of this problematique. Critical components of human security are food, water, livelihoods, land and health, which are going to be seriously affected by the multiple and interrelated impacts of growing environmental scarcity. Though the severity of the challenges demands a coordinated global plan of action, the lack of basic trust between the developed and developing countries has become the primary hurdle towards this endeavour.

So, at bottom of the debate on environment and security we have two moving targets, the nexus of which is difficult to pin-point with accuracy at this stage. We are nevertheless obligated to frame this emerging field in the most complete possible way, which is the ultimate aim of this Handbook and the broad compilation of contributions to this effort. In doing this, the two foremost challenges are the scope and nature of the coming environmental changes and scarcities, as well as perceptions of and strategies for maintaining (human) security on micro as well as macro levels. Below, we present a review, first, on how the alternative security debate relates to environmental issues and, second, which range of environmental scarcities is predominant in this process. The end of the chapter will review how the contributions of this volume contribute to the overall problematique and how the volume is structured to illuminate this.

\section{ALTERED SECURITY CONCEPTIONS}

Most, if not all, security apparatuses in the world are mainly geared towards protecting borders and securing states from other states' possible aggression. They are, moreover, designed to do so by military means and/or through their capacity to exert violence (or the threat thereof). As such, they are enacting the classic realist security paradigm (Carr 1939; Morgenthau 1948; Waltz 1979; Buzan 1983), based on the conception of international anarchy and felt through the security dilemma (Herz 1950; Jervis 1978). The experience of the First World War, analysis of the Second World War, and the intensity of the Cold War (up to 1991) have further fuelled these mechanisms, solidifying it as a globally accepted norm within international relations. Enormous amounts of financial, intellectual and material resources have been invested in the upholding of these perceptions. Even so, with the collapse of the Cold War, a deepened understanding of threats, and a shift in the underlying conditions and evolving global society, this paradigm has been questioned from a range of perspectives in a flurry of arguments under 
the notion of critical security studies in an alternative security debate (Barnett 2001; Peoples and Vaughan-Williams 2014).

An opposing theoretical perspective to the prevailing realism is functionalism, which focuses on integration and has a primary goal not of state security as realism, but more on peace and prosperity through cooperation and integration at regional and global levels. Collective governance and material interdependence are what is strived for between states as technical and economic cooperation is advanced (Mitrany 1933; Haas 1958, 1964). Cooperation in sectors of "low" political importance builds trust over time and can be further expanded to broader, and less benevolent, areas. Against this backdrop, developments such as the European Union and the multilateral system were developed. While realism focuses on power as the main means to achieve security, the functionalist perspective focuses on collaboration as the means to achieve it.

Within security studies the predominant approach has traditionally been to view security from an "objective" view. In other words, what is seen as a clear threat to the stability and security of the state is what matters. However, from a constructivist approach it was later argued that there is neither a natural law nor scientific precision in this understanding of security. "Anarchy", Wendt claims, "is what states make of it" (Wendt 1992), opening up other perceptions of and strategies for the upholding of security. Most evolving critiques focus on the referent object of "security" and the means of upholding it. While the realist school has almost entirely focused on state/nation security, alternative debate has introduced forcefully the question "whose security?", creating a revolution in the security debate. Women, the elderly, minorities, regions, the poor, or humans at large have all become possible referent objects for security studies.

A forceful strand of feminist critics has pointed out that traditional security conceptions are male-based, generally ignoring the day-to-day insecurities that women often experience in vulnerable places or even targeting through actions of deliberate sexual violence (Baaz and Stern 2013: xx). They have shown convincingly the magnitude of violence towards and insecurity of women, calling for a rethinking/refocusing of the concept. Postcolonial critique of the concept has focused its lens on the role of realist security perceptions upholding a global hierarchy through certain mechanisms and processes related to security perceptions (Duffield 2010), occasionally based in racism and "othering" (cf. Said 1978). In particular, eurocentrism and the hegemony of the European political history and models are phenomena for postcolonial critique (Chandler 2012). There was/is also an explicit discursive approach, characterising security as a "speech act" (as in the Copenhagen school; cf. Buzan et al. 1998) where the hegemonic interests securitise fields and processes, making them unattainable for anyone but "the right" actors. Then these are monopolised through their prioritised position and material resources in a self-serving spiral. Following on from the constructivist approach, they argue that security is not an objective feature of threats, in contrast to the traditional approach in security studies. This opened up the debate for considering new aspects affecting security, including environmental ones.

The broadest - and possibly the most internalised in the mainstream security debate - of these critiques of the classic realist security paradigm is the term human security, heralded initially by the United Nations Development Programme (UNDP 1994). It places humans (instead of states) at the centre and from there asks what will improve the security of humans. This is then bound to differ depending on time and place, and on who is in focus, but the approaches are centred on economic, food, health, environmental, personal, community and 
political security. It thus has a clear connection to the development debate (for instance, through the security-development nexus (Stern and Öjendal 2010)). The concept can be seen as transformative and emancipating through its focus on humans and human agency (Chandler 2012), but it has also been criticised for being fluffy and easily co-opted by hegemonic discourses, exploiting it for whatever interests (and typically by those who it is supposedly challenging) (Turner et al. 2010: 83-96).

This takes us to the core of the matter and the long-since established term "environmental security" itself. This debate goes back to the "silent spring" of the early 1960s (Carson 1962) and the canonic This Endangered Planet by Richard Falk (1972), calling attention to the long-term and at the time invisible consequences of environmental degradation, to Lester Brown's heroic attempts to securitise the environmental debate in the 1970s (Brown 1977; cf. Mathews 1989), and to Ullman's (1983) and Westing's (1986) insertion of environment into the core of the security discourse in the 1980s. All these early calls for linking environmental concerns with security issues date back to an era before the alternative security debate had made a dent in the mainstream realist hegemonic control of the realms of "security". In hindsight, these were crucial preludes to the contemporary debate, but, as changes in academic approaches and perspectives takes time and a critical mass (Kuhn 1962), it could not immediately destabilise the hegemonic mainstream security structure and its priorities in a deep sense. Post-Cold War and in concert with the critique reviewed above, environmental security came, in contrast, to develop a serious challenge to business as usual (cf. Homer-Dixon and Levy 1995; Lowi and Shaw 2000; Barnett 2001). As part of this, the constructivist approach appearing in the 1990s provided a framework of sorts that also allowed for the inclusion of environmental aspects, for example.

Water scarcity was (for a while) predicted to generate "water wars"; resource scarcities were predicted to generate violent conflicts (Cooley 1984; Starr 1991; Homer-Dixon 1994); and the connection to forced large-scale migration was made (Swain 1996), all showing beyond doubt that security issues in relation to environmental change and degradation were very real and needed to be brought centre stage. Using water as an illustrative example, the discourse evolved as follows. The early analysis focusing on water as a reason for violent conflict and even war was largely based on the situation in the Middle East and North Africa (MENA) region. In the region a number of countries were already in a situation where the natural water they had access to did not suffice to sustain the food production that was needed for the population to be self-sufficient. Coupled with statements from political leaders in the region saying that the next war would be about water, the case was made. While water, following Buzan et al. (1998), became the referent object in a process of securitisation, at the same time, and perhaps paradoxically, the underlying theoretical perspective was one of realism where the security of the state is the primary objective, thus leading to a zero-sum perspective being employed where competition between states sharing the resources is the primary interpretation of the situation. Needless to say, a zero-sum perspective encourages a conflicting mindset also on water as a resource. What was later highlighted was that the analyses did not take into account political economy perspectives (Allan 1996, 2001). As analysis of global trade data would show, when MENA countries were "running out of water" they addressed the shortfall not through waging war on their neighbours, but through virtual water imports. As environmental perspectives entered the discourse it became clear that the traditional security analysis was inadequate for a deeper understanding. In addition, more quantitative research on transboundary water showed that predominantly water had been a source of cooperation rather 
than conflict (Wolf 1995; Wolf et al. 2005). As the debate was transformed, the theoretical lens shifted to a more functionalist perspective, which also is a critique of the predominant perspective or realism in international relations theory, and, in principle, argues that cooperation on "low politics", such as water, may be something that can spur cooperation in other, more sensitive, political areas.

From the early 1990s, and as exemplified looking at water, Pandora's box had been opened and a wealth of environmental issues carried security implications (and were increasingly recognised to do so), including such phenomena as drought, flooding, desertification, biodiversity, deforestation, soil erosion, water scarcity, water quality, (declining) food production, salinisation, air pollution, greenhouse gas emissions, toxification and global climate change (Earle et al. 2010). These affect humans either in a globally structural way or in a more localised but merciless way. As these issues deepen and spread (while population pressure increases and vulnerability proliferates), the security dimension becomes all the more obvious as dysfunctional environmental systems quickly put people and their livelihoods in jeopardy.

As the global climate change became inevitable to ignore, the systemic effects of over-consumption of fossil fuels obvious, and the impact on global climate turned critical (Adger et al. 2014), another dimension was added to the significance of environmental security. Now it was no longer "only" border communities, forced migration, vulnerable groups or specific sectors that were at stake due to particular environmental dysfunctions, but a broad systemic threat, potentially encompassing all humanity globally in a wide and unavoidable trend. As such, the referent object "environment" to security has turned into a quest for saving "humankind" or possibly "the global ecosystem", constituting, we believe, one of the most worthwhile tasks imaginable. Although highly worthwhile, this does not diminish the massive challenge of "collective action" (Ostrom 1990) that needs to be overcome in order to govern this process in an anarchic world. In this respect, institutional perspectives offer some useful perspectives - here, the formal and informal rules that are being developed over time through interaction between actors (states) coalesce into a "regime" by which cooperation can happen and become further institutionalised. The focus is the normative institution which deals with a specific issue and to which states create and subscribe to voluntarily, as a means of self-regulation in the international arena on a broad array of topics including the environment (Mayer et al. 1993). Keohane (1984: 97) furthermore holds that:

\footnotetext{
International regimes are useful to governments. Far from being threats to governments (in which case it would be hard to understand why they exist at all), they permit governments to attain objectives that would otherwise be unattainable. They do so in part by facilitating intergovernmental agreements. Regimes facilitate agreements by raising the anticipated costs of violating others' property rights, by altering transaction costs through the clustering of issues, and by providing reliable information to members. Regimes are relatively efficient institutions, compared with the alternative of having a myriad of unrelated agreements, since their principles, rules, and institutions create linkages among issues that give actors incentives to reach mutually beneficial agreements. They thrive in situations where states have common as well as conflicting interests.
}

Having said all this, obviously, the state-oriented and military-based realist security perception still dominates the international scene and resource allocations, but the above alternative and critical security debate has opened up the possibility of taking a wide range of security threats into consideration. In doing so, we argue, the degrading environment - its changes, scarcities, (increasing) unreliability, and its direct impact on people and their livelihoods - is 
growing into a paramount security concern (see next section), by far underestimated hitherto by national elites, global policymakers and security analysts alike. If we are right (and many would agree), environmental degradation constitutes a (or the) major security threat on a global scale, whereas most thinking and resources for generating security is directed towards military means and traditional security apparatuses. This is a critical mismatch in the contemporary world.

\section{REAL AND FEARED THREATS FROM ENVIRONMENTAL DEGRADATION (INCLUDING CLIMATE CHANGE)}

So, which explicit threat towards security are we feeling and fearing from environmental degradation and global climate change? Can we substantiate the claimed imperative of attention to environmental security? The idea is certainly creeping into established security institutions (although not necessarily into their budgets), for instance, as expressed in a report commissioned by the US Army Environmental Policy Institute:

Climate change and unconventional security issues - impervious to national sovereignty, ideology, and military power - are now recognized as top threats to peace, political stability, and prosperity. The role of environmental diplomacy is growing and environmental security-related concerns are becoming defining factors in international political and military negotiations. (Glenn et al. 2010: 1)

The significance of this seems not to be overestimated, given available data. Although respecting the difficulties of collecting reliable data and the precariousness of projecting global trends, the International Organization for Migration (IOM), for instance, states that by 2050 there may be anywhere between 25 million and 1 billion environmental refugees, and by 2100 possibly 1-2 billion (IOM 2014). In the same report, the Internal Displacement Monitoring Centre (IDMC) is cited, claiming that “ ... a total of 165.9 million people were newly displaced in the five year period of 2008-2013. In four out of the last five years, over 90 per cent of displacement was related to climate and weather disasters" (see IOM 2014: 139).

Moreover, the Global Peace Index (GPI) states that:

The effects of climate shocks on factors such as resource scarcity, livelihood security and displacement can greatly increase the risk of future violent conflict, even when climate change does not directly cause conflict. ... An estimated 971 million people live in areas with high or very high exposure to climate hazards, putting them at risk for both extreme weather events and breakdowns in peacefulness in the coming decades. (GPI 2019)

The Millennium Project, as cited above (Glenn et al. 2010), further concludes that resource-/ environmentally-based conflicts have a particular precariousness: "While conflicts involving natural resources are twice as likely to relapse in the five years following a peace agreement, UNEP [United Nations Environment Programme] notes that fewer than 25\% of relevant peace agreements address environmental or resource aspects" (Glenn et al. 2010: 3), and that "NATO's Strategic Concept for the next decade stipulates that the world's security environment and the organization's planning and operations will be increasingly shaped by key environmental and resource challenges such as climate change, water and food scarcity, and growing energy needs" (ibid.: 2). 
In 2015, a G7-commissioned report was presented which states in no uncertain terms that "Climate change is a global threat to security in the 21st century" (Rüttinger et al. 2015). It went on to emphasise that "Climate change will stress our economic, social, and political systems. Where institutions and governments are unable to manage the stress or absorb the shocks of a changing climate, the risks to the stability of states and societies will increase" (ibid.). In this context they also pointed out that "The sharpest risks emerge when the impacts of climate change overburden weak states. Climate change is the ultimate 'threat multiplier': it will aggravate already fragile situations and may contribute to social upheaval and even violent conflict" (ibid.). As a continuation of this analysis, in order to reduce insecurities, the report emphasises the need to incorporate environmental and climate change issues into peacebuilding structures:

While leading peacebuilding and security actors, including the UN Security Council, have called for a better understanding of the links between climate and fragility, climate change is not yet sufficiently incorporated explicitly into fragility or peace and conflict assessments. While many different assessment tools focus attention on climate change, natural resources, or conflict, very few integrate all three dimensions. (Rüttinger et al. 2015: 9)

Building on this G7-commissioned report, UNEP, one of the UN agencies working explicitly with the environment-security link, assesses the following seven areas as particularly prone to insecurities as a result of changing/degrading environment: Local resource competition; livelihood insecurity and migration; extreme weather events and disasters; volatile food prices and provision; transboundary water management; sea-level rise and coastal degradation; unintended effects of climate policies (UNEP n.d.). Some of these - such as local resource competition and (forced) migration - we recognise as dating back to the well-known environment-security debate from the 1990s, whereas others - such as sea-level rise and coastal degradation, and extreme weather events and disasters - are more connected to recent notions of global climate change. What they have in common is that they are distinctly connected to the common ability to uphold peace and security.

Moreover, the Intergovernmental Panel on Climate Change (IPCC), the leading global body working on the nature and impact of global climate change, made, in their 2014 report, an explicit connection between climate change and human security. They stated (in their particular terminology) that: "Human security will be progressively threatened as the climate changes (robust evidence, high agreement)" (IPCC 2014: 758). Hence, the IPCC is convinced, although humble in their understanding of isolated and distinct causal connections, that environmental factors in general and climate change in particular are connected to aspects of human security. Even so, and very much in the spirit of this Handbook, they also emphasise that

Many climate change risks to human security warrant further investigation. There is a need for more comprehensive evidence, collected across multiple locations, and over long durations, to build and test theories about relationships between climate change and livelihoods, culture, migration, and conflict. (IPCC 2014: 760)

Even a traditionally development-focused global institution such as the World Bank has highlighted the role of environmental factors from a conflict perspective in its recent World Bank Group Strategy on Fragility, Conflict and Violence (FCV) in which one of its four pillars, which provides guidance on how to engage and what to aim for, reads: 
Mitigating the spillovers of FCV to support countries and the most vulnerable and marginalized communities that are impacted by cross-border crises, such as forced displacement or shocks resulting from famines, pandemics, and climate and environmental challenges. (World Bank 2020)

There are many more examples on research and policy reports that make the connection, emphasise the seriousness, and call for more intensive action in order to secure global security. Based on this conviction and rising trends, this Handbook aims to uncover a vast field of issues where environmental and security concerns lock horns and become indisputably interconnected. Below, we will display how, and with which effect, global research has taken on these issues and what the state-of-the-art is in contemporary research.

\section{OUTLINE OF THIS VOLUME}

The Handbook contains 22 chapters and is organised in four parts. Chapter 1 opens up the scene and seeks to explore borders between and links across the two themes of security and environment, while providing the anatomy of this emerging field. The five chapters in Part II of the handbook deal with macro processes of environmental security, while the ten chapters in Part III address micro processes of environmental security. Finally, six chapters in Part IV explain and analyse actors and processes engaged with environmental security. The chapters in Part II have been selected as they identify the macro/structural force and the undeniable significance with which environmental issues are making their way into the spotlight of security discourse. Topics include a focus on security issues stemming from environmental crisis, climate change, water scarcity and sharing, and future challenges over food and land use. Part III focuses on a series of representative cases where environmental issues have led to a security crisis or security cooperation. The chapters in this section of the Handbook cover South East Asia, Central Asia, China, India, Nepal, the Middle East, West Africa, South Africa and Mexico. Part IV of the Handbook covers actors and processes engaged with environmental security and includes chapters on the role and view of the UN system, major social movements, and the engagement of non-governmental organisations (NGOs) and epistemic communities.

As part of the macro processes of environmental security, James R. Lee analyses the security dynamics of migration due to growing population and global climate change (Chapter 2, "Scarcity, Abundance and Migration"); Simon Dalby argues for the need for novel security strategies in the context of climate emergency (Chapter 3, "Global Climate Change and Security Threats"); Larry Swatuk argues for the expansion of the framing of water security and not to tie it only to sovereign states (Chapter 4, "Global Water Crises and Challenges for Water Security”); David Michel, Mats Eriksson and Martina Klimes ask for integrated and cooperative approaches among water users at all levels due to rising water demands and global climate change (Chapter 5, "Climate Change and (In)Security in Transboundary Basins"); and Adan E. Suazo shows how the resource abundance theory does not account for freshwater abundance as a potential determinant in resource conflict (Chapter 6, "Revisiting Freshwater Abundance within the Peace and Conflict Discourse").

Covering micro processes of environmental security, Mats Hårsmar explores the link between climate change-induced resource scarcity and violent conflicts by non-state armed groups in West Africa (Chapter 7, "Environment and Security in West Africa"); Sethulego Matebesi shows the harmful environmental effects of mining in South Africa (Chapter 8, 
"Mining, Environmental Changes and Human Security in South Africa"); Celeste Cedillo and Juan Antonio Le Clercq discuss the lack of institutional capacity and political will of Mexican authorities to investigate and prosecute violence against activists opposing illegal resource extraction (Chapter 9, "Green Impunity"); Elliot Brennan shows how climate change acts as a threat multiplier in Southeast Asia (Chapter 10, "Climate Change and Security Threats in Southeast Asia"); Mely Caballero-Anthony and Margareth Sembiring analyse various causes of environmentally induced threats in Southeast Asia and what should be done to achieve environmental security (Chapter 11, "Cases and Implications of Environmental Insecurity in Southeast Asia"); Vakur Sümer, Dauren Aben and Zhengizkhan Zhanaltay analyse the major environmental problems and energy-related issues in Central Asia along with their security implications (Chapter 12, "Environment and Energy in Central Asia"); Zhijian Wang and Samuel Smith argue that though China's water and environmental security regimes have entered a new phase of improved governance, the country still faces a multitude of water security issues that need to be addressed (Chapter 13, "Water and Environmental Security in China"); Jayati Srivastava shows how security is narrowly defined in India while covering environmental issues and argues for a change of approach (Chapter 14, "Environment and Security in India"); Bishnu Raj Upreti provides an overview of major environmental concerns in Nepal and analyses the main factors contributing to environmental and human insecurity in the country (Chapter 15, "Nepal: Reflections on the Environmental and Human Security Debate"); and Nadim Farajalla, Elie Dib, Olivia Macharis and Emil Kaston show the complex links between environment and conflicts in the Middle East region (Chapter 16, "Security and Environment in the Middle East").

In the final part of the Handbook, which deals with actors and processes engaged with environmental security, Martin Wall and Janani Vivekananda analyse the UN Security Council's handling of climate change and provide a possible path for its future engagement with environmental matters (Chapter 17, "Climate Change and the Environment at the UN Security Council"); Shafiqul Islam and Enamul Choudhury ague for pragmatic actionable steps to be taken in order to be adaptive in addressing scarcity-sustainability-security dynamics (Chapter 18, "Understanding and Framing Scarcity, Sustainability and Security"); Barbara Magalhães Teixeira explores the relationship between natural resources and climate change and how they can not only lead to conflicts but also positively affect peace (Chapter 19, "The Environment of Lasting Peace"); Mark Nuttall shows that the world of environmental crime has many additional factors which are more pronounced than other crime types (Chapter 20, "Bribery, Corruption, Geopolitics and Investigation"); Huiyi Chen looks at the ongoing rapid transition of global energy systems towards renewable energy production (Chapter 21, "Renewable Energy, Security and Environment"); and Dorte Verner and Edinaldo Tebaldi present and discuss characteristics of the refugee population who may benefit due to the introduction of climate-smart agriculture technologies (Chapter 22, "Displaced Populations, Food Security and Frontier Agriculture"). 


\section{REFERENCES}

Adger, W.N., J.M. Puhlin, J. Barnett, G.D. Dabelko, G.K. Hovelsrud, M. Levy, Ú. Oswald Spring and C.H. Vogel, 2014, "Human security", in C.B. Field, V.R. Barros, D.J. Dokken, K.J. Mach, M.D. Mastrandrea, T.E. Bilir, M. Chatterjee, K.L. Ebi, Y.O. Estrada, R.C. Genova, B. Girma, E.S. Kissel, A.N. Levy, S. MacCracken, P.R. Mastrandrea and L.L. White (eds), Climate Change 2014: Impacts, Adaptation, and Vulnerability. Part A: Global and Sectoral Aspects. Contribution of Working Group II to the Fifth Assessment Report of the Intergovernmental Panel on Climate Change, Cambridge, UK, and New York: Cambridge University Press, 755-91.

Allan, J.A., 1996, "Policy Responses to the Closure of Water Resources: Regional and Global Issues", in P. Howsam and R. C. Carter (eds), Water Policy: Allocation and Management in Practice, London: Chapman and Hall, 3-12.

Allan, J.A., 2001, The Middle East Water Question: Hydropolitics and the Global Economy, London: I.B. Tauris.

Baaz, Maria-Eriksson and Maria Stern, 2013, Sexual Violence as a Weapon of War? Perceptions, Prescriptions, Problems in the Congo and Beyond, London: Zed Books.

Barnett, Jon, 2001, The Meaning of Environmental Security: Ecological Politics and Policy in the New Security Era, London: Zed Books.

Brown, Lester, 1977, Redefining National Security, Worldwatch Paper 14, Washington, DC: Worldwatch Inst.

Buzan, B., 1983, People, States \& Fear: The National Security Problem in International Relations, London: ECPR Press.

Buzan, B., O. Waever and J. de Wilde, 1998, Security: A New Framework for Analysis, Boulder, CO and London: Lynne Rienner.

Carr, D.H., 1939, The Twenty Years' Crisis, 1919-1939: An Introduction to the Study of International Relations, London: Macmillan.

Carson, Rachel, 1962, Silent Spring, Boston, MA: Houghton Mifflin.

Chandler, David, 2012, "Resilience and Human Security: The Post-interventionist Paradigm", Security Dialogue, Vol. 43, No. 3, 213-29.

Cooley, John K., 1984, "The War over Water”, Foreign Policy, Vol. 54 (Spring), 3-26.

Duffield, Mark, 2010, "The Liberal Way of Development and the Development-Security Impasse: Exploring the Global Life-Chance Divide”, Security Dialogue, Vol. 41, No. 1, 53-76.

Earle, A., A. Jägerskog and J. Öjendal (eds), 2010, Transboundary Water Management: From Principles to Practice, London: Earthscan.

Falk, Richard A., 1972, This Endangered Planet: Prospects and Proposals for Human Survival, London: Vintage Books.

Gayoom, A., 1987, "Environment and Development", speech before the 42nd session of the United Nations General Assembly on the special debate on environment and development, 19 October.

Glenn, Jerome C., Theodore Jay Gordon and Elizabeth Florescu, 2010, 2010: State of the Future, Washington, DC: The Millenium Project.

GPI, 2019, "Global Peace Index 2018”, http://visionofhumanity.org/indexes/global-peace-index/.

Haas, Ernst B., 1958, The Uniting of Europe: Political, Social, and Economic Forces, 1950-1957, Stanford, CA: Stanford University Press.

Haas, Ernst B., 1964, Beyond the Nation State, Stanford, CA: Stanford University Press.

Herz, John H., 1950, "Political Ideas and Political Reality", Political Research Quarterly, Vol. 3, No. $2,161-78$.

Homer-Dixon, Thomas F. and Marc A. Levy, 1995, "Environment and Security”, International Security, Vol. 20, No. 3, 189-98.

Homer-Dixon, Thomas F., 1994, "Environmental Scarcities and Violent Conflict - Evidence from Cases", International Security, Vol. 19, No. 1, 5-40.

IOM, 2014, IOM Outlook on Migration, Environment and Climate Change, Geneva: IOM.

IPCC, 2014, "Climate Change 2014: Impacts, Adaptation, and Vulnerability", Technical Summary, IPCC.

IPCC, 2019a, IPCC Special Report on the Ocean and Cryosphere in a Changing Climate [eds H.-O. Pörtner, D.C. Roberts, V. Masson-Delmotte, P. Zhai, M. Tignor, E. Poloczanska, K. Mintenbeck, A. Alegría, M. Nicolai, A. Okem, J. Petzold, B. Rama, N.M. Weyer], https://www.ipcc.ch/srocc/. 
IPCC, 2019b, Climate Change and Land, an IPCC Special Report on Climate Change, Desertification, Land Degradation, Sustainable Land Management, Food Security, and Greenhouse Gas Fluxes in Terrestrial Ecosystems, https://www.ipcc.ch/srccl/.

Jervis, Robert, 1978, "Cooperation under the Security Dilemma", World Politics, Vol. 30, No. 2, $167-214$.

Keohane, R., 1984, After Hegemony, Princeton, NJ: Princeton University Press.

Kuhn, Thomas, 1962, The Structure of Scientific Revolutions, Chicago, IL: Chicago University Press.

Lowi, M. and B. Shaw (eds), 2000, Environment and Security: Discourses and Practices, London: Palgrave Macmillan.

Mathews, Jessica, 1989, "Redefining Security”, Foreign Affairs, Vol. 68, No. 2, 162-77.

Mayer, P., V. Rittberger and M. Zürn, 1993, "Regime Theory: State of the Art and Perspectives", in V. Rittberger (ed.), Regime Theory and International Relations, Oxford: Clarendon Press, 391-430.

Mitrany, David, 1933, The Progress of International Government, New Haven, CT: Yale University Press.

Morgenthau, Hans, 1948, Politics among Nations: The Struggle for Power and Peace, New York: Alfred A. Knopf.

Ostrom, Elinor, 1990, Governing the Commons, Cambridge: Cambridge University Press.

Peoples, Columba and Nick Vaughan-Williams, 2014, Critical Security Studies: An Introduction, London: Routledge.

Rüttinger, Lukas et al., 2015, A New Climate for Peace - Taking Action on Climate and Fragility Risks, adelphi, International Alert, the Wilson Center, the European Union Institute for Security Studies.

Said, Edwars, 1978, Orientalism, London: Pantheon Books.

Starr, J.R., 1991, "Water Wars", Foreign Policy, Vol. 82 (Spring), 17-36.

Stern, M. and J. Öjendal, 2010, "Mapping the Security-Development Nexus: Conflict, Complexity, Cacophony, Convergence?", Security Dialogue, Vol. 41, No. 1, 5-29.

Swain, Ashok, 1996, "Environmental Migration and Conflict Dynamics: Focus on Developing Regions", Third World Quarterly, Vol. 17, No. 5, 959-73.

Turner, Mandy, Neil Cooper and Michael Pugh, 2010, "Institutionalised and Co-opted: Why Human Security Has Lost Its Way”, in David Chandler and Nik Hynek (eds), Critical Perspectives on Human Security: Rethinking Emancipation and Power in International Relations, London: Routledge, Chapter 7.

Ullman, H., 1983, "Redefining Security”, International Security, Vol. 8, No. 1, 129-53.

UNDP, 1994, Human Development Report, New York: United Nations.

UNEP, n.d., Climate Change and Security: Strengthening Resilience to Climate-Fragility Risks, https:// postconflict.unep.ch/publications/ClimateChange_Security_twopager.pdf.

University of Bern, 2019, "Climate is warming faster than it has in the last 2,000 years", ScienceDaily, 24 July.

USGCRP, 2018, Impacts, Risks, and Adaptation in the United States: Fourth National Climate Assessment, Volume II [ed. D.R. Reidmiller, C.W. Avery, D.R. Easterling, K.E. Kunkel, K.L.M. Lewis, T.K. Maycock and B.C. Stewart], Washington, DC: US Global Change Research Program.

Vaughan, Adam, 2019, "IPCC Report: Sea Levels Could be a Meter Higher by 2010", New Scientist, 23 September.

Waltz, Kenneth, 1979, Theory of International Politics, Reading, MA: Addison-Wesley.

Wendt, Alexander, "Anarchy Is what States Make of It: The Social Construction of Power Politics", International Organization, Vol. 46, No. 2, 391-425.

Westing, Arthur H. (ed.), 1986, Global Resources and International Conflicts: Environmental Factors in Strategic Policy and Action, Stockholm: SIPRI.

Wolf, A., 1995, Hydropolitics along the Jordan River: Scarce Water and Its Impact on the Arab-Israeli Conflict, Tokyo: United Nations University Press.

Wolf, A., A. Kramer, A. Carius and G.D. Dabelko, 2005, "Managing Water Conflict and Cooperation", in State of the World: Redefining Global Security, Washington, DC: World Watch Institute.

World Bank, 2020, World Bank Group Strategy for Fragility, Conflict, and Violence 2020- 2025 (English), Washington, DC: World Bank Group. 